\title{
Gene therapy for inborn errors of liver metabolism: progress towards clinical applications Nicola Brunetti-Pierri
}

Address: Department of Molecular and Human Genetics, Baylor College of Medicine, Houston, TX, USA

Email: Nicola Brunetti-Pierri - nicolab@bcm.tmc.edu

Published: 18 November 2008

Italian Journal of Pediatrics 2008, 34:2 doi:10.1 |86//824-7288-34-2

This article is available from: http://www.ijponline.net/content/34/I/2

(c) 2008 Brunetti-Pierri; licensee BioMed Central Ltd.

This is an Open Access article distributed under the terms of the Creative Commons Attribution License (http://creativecommons.org/licenses/by/2.0), which permits unrestricted use, distribution, and reproduction in any medium, provided the original work is properly cited.
Received: 7 October 2008

Accepted: 18 November 2008

\begin{abstract}
The treatment for inborn errors of liver metabolism is based on dietary, drug, and cell therapies (orthotopic liver transplantation). However, significant morbidity and mortality still remain, and alternative strategies are needed. Gene replacement therapy has the potential of providing a definitive cure for patients with these diseases. Significant progress has been made in the pre-clinical arena and achievement of efficacy in different animal models has been reported using multiple gene transfer technologies. This article summarizes the gene transfer strategies being investigated, the pre-clinical data, and the available early clinical results for inborn errors of liver metabolism.
\end{abstract}

\section{Introduction}

Significant advances in the diagnosis and treatment of inborn errors of metabolism have occurred in recent years. Expanded newborn screening using tandem mass spectrometry has led to the ability to identify and treat neonates who have metabolic conditions before symptoms appear [1]. Developments in nutritional support and pharmacological treatments with vitamin cofactors, end-product replacement, and drugs inducing specific enzymes or alternative pathways have also led to better outcomes. Cell therapy, primarily orthotopic liver transplantation (OLT), has significantly changed the prognosis of some of these diseases. Patients undergoing solid organ transplantation have benefited from innovative surgical techniques and novel, less toxic nonsteroidal immunosuppressive regimens. However, pharmacological treatments are often insufficient in the face of the activation of catabolic states, many patients succumb while waiting for a donor organ (approximately 15\%), and short-term peritransplant morbidity and long-term morbidity associated with lifelong immunosuppression continue to be significant issues [2-5]. Therefore, a risk/benefit assessment could make gene therapy an acceptable option for several inborn errors of metabolism.

Progress in the direction of clinical application of gene replacement therapy has been scarce so far despite extensive investigations for over 20 years. A general skepticism toward gene therapy was raised by the death of one patient in the ornithine transcarbamylase deficiency (OTCD) clinical trial [6] and by the recent report of leukemia occurred in few patients with severe combined immunodeficiencies (SCID) treated with retroviral ex vivo gene therapy [7]. However, with regard to the SCID trial, it is important to emphasize that despite the adverse events, it clearly demonstrated the benefits of gene therapy as treated patients can now cope with environmental microorganisms and live a normal life in the absence of any specific therapy [8].

Several different types of vectors, both viral and nonviral, have been developed for liver-directed gene therapy and have resulted in phenotypic correction in numerous animal disease models. The optimal vector for in vivo liver- 
directed gene therapy should be able to transfer genes to a high percentage of hepatocytes with limited toxicity. However, the available vectors have all shown some limitations (Table 1). In aiming at the treatment of liver metabolic diseases an important issue is how much of the liver needs to be corrected (i.e. percentage of hepatocyte) to achieve clinically relevant improvements. The percentage of hepatocyte transduction required for phenotypic correction is generally low in non-cell autonomous disorders such as hemophilia A and B or mucopolysaccharidoses and higher in cell autonomous defects such as urea cycle disorders. As a general principle, maximizing therapeutic gene expression per cell and minimizing the vector dose for a clinical effect are desirable. However, the potential adverse effects of over-expression of the therapeutic protein should also be taken into account.

\section{Vectors for liver directed gene therapy}

The number of different vectors that are under development for liver-directed gene therapy is continuously increasing. However, five main classes of vectors have been more extensively investigated and each of these classes is characterized by different strengths and weaknesses (Table 1).

\section{Retrovirus}

Retroviral vectors (RV) were the first vectors used for gene therapy. They can efficiently integrate into the chromatin of target cells. However, they require the target cells to be mitotically active for an efficient transduction. Therefore, induction of liver division or liver regeneration through manipulations such as partial hepatectomy or hapatocyte growth factor treatment have been required for efficient hepatocyte transduction [9-11]. More recently, it has been shown that RV can transduce hepatocytes from newborn mice [12] and dogs [13] without an exogenous stimulation of cell division. However, as shown by the SCID trial experience, the risk of insertional mutagenesis is still a major consideration for RV.

\section{Lentivirus}

Lentivirus vectors (LV) offer similar advantages to the RV, in that they mediate long-term integration of the therapeutic transgene, but unlike RV, they do not require cellular mitosis to gain access to the host genome for integration. They also are thought to share the potential for insertional mutagenesis with subsequent carcinogenesis, although this has not been observed yet in animal models. Following systemic LV delivery, the majority of transduced liver cells are of nonparenchymal origin and

Table I: Overview of gene therapy vectors.

\begin{tabular}{|c|c|c|c|c|c|}
\hline & Genetic material & Packaging capacity & Vector genome forms & Advantages & Disadvantages \\
\hline \multirow[t]{3}{*}{ Retrovirus } & RNA & $8 \mathrm{~kb}$ & Integrated & $\begin{array}{l}\text { - High efficiency } \\
\text { integration }\end{array}$ & $\begin{array}{l}\text { - Transduction only in } \\
\text { dividing cells }\end{array}$ \\
\hline & & & & $\begin{array}{l}\text { - No viral immune } \\
\text { response }\end{array}$ & $\begin{array}{l}\text { - Insertional } \\
\text { carcinogenesis }\end{array}$ \\
\hline & & & & - Long-term expression & \\
\hline \multirow[t]{2}{*}{ Lentivirus } & RNA & $8 \mathrm{~kb}$ & Integrated & - Non-dividing cells & $\begin{array}{l}\text { - Integration into active } \\
\text { genes }\end{array}$ \\
\hline & & & & - Long-term expression & $\begin{array}{l}\text { - Risk of replication } \\
\text { competent HIV }\end{array}$ \\
\hline \multirow[t]{4}{*}{ Adenovirus } & dsDNA & Up to $35 \mathrm{~kb}$ (HDAd) & Episomal & - Non-dividing cells & - Acute toxicity \\
\hline & & & & - Large cloning capacity & \\
\hline & & & & $\begin{array}{l}\text { - High transduction } \\
\text { levels }\end{array}$ & \\
\hline & & & & $\begin{array}{l}\text { - Long-term expression } \\
\text { (HDAd) }\end{array}$ & \\
\hline \multirow{2}{*}{$\begin{array}{l}\text { Adeno-associated } \\
\text { vectors }\end{array}$} & ssDNA & $5-9 \mathrm{~kb}$ & Episomal (> 90\%) & - Non-dividing cells & - Limited cloning capacity \\
\hline & & & Integrated $(<10 \%)$ & - Long-term expression & $\begin{array}{l}\text { - CTL-mediated immune } \\
\text { reaction }\end{array}$ \\
\hline \multirow[t]{5}{*}{ Naked plasmid DNA } & dsDNA & Unlimited & Episomal & - Non dividing cells & $\begin{array}{l}\text { - Low efficiency of } \\
\text { transduction }\end{array}$ \\
\hline & & & & $\begin{array}{l}\text { - No inflammatory } \\
\text { response }\end{array}$ & $\begin{array}{l}\text { - Efficient and clinically } \\
\text { relevant delivery method } \\
\text { still to be developed }\end{array}$ \\
\hline & & & & - Large cloning capacity & \\
\hline & & & & - Long-term expression & \\
\hline & & & & - Ease preparation & \\
\hline
\end{tabular}

dsDNA = double stranded DNA; ssDNA = single stranded DNA; HDAd = helper-dependent adenoviral vector; $C T L=$ cytotoxic $T$ lymphocyte. 
therefore, the efficiency of hepatocyte transduction is relatively low.

\section{Adenovirus}

Adenovirus (Ad) vectors are well suited for liver-directed gene therapy because they can transduce hepatocytes with high efficiency. When tested in vivo, first generation of Ad (FGAd) vectors, which are replication-defective but can still express viral genes at low levels, cause acute and chronic toxicity. Helper-dependent adenoviral (HDAd) vectors, which are devoid of all viral genes, offer a better safety profile and can provide long-term transgene expression with negligible chronic toxicity [14]. Several preclinical studies have shown that HDAd results in long-term phenotypic correction in several genetic diseases [14]. However, similar to FGAd they can still cause an acute toxic reaction due to activation of the host innate immune system when they are administered at high dose systemically [15]. A clinical trial for OTCD using an early generation Ad vector bearing the human OTC gene was interrupted when the second subject at the highest dose suffered fatal complications. The trial involved 18 subjects divided into 6 cohorts of $1 / 2$ log dose escalations between cohorts until two subjects were enrolled at the highest dose [16]. As predicted from preclinical models, clinical findings were mild and transient in the initial 17 patients [16]. However, unlike the previous subjects, the last patient enrolled developed within 24 hours after vector infusion a lethal reaction characterized by acute respiratory distress syndrome, hepatitis, disseminated intravascular coagulopathy, hyperammonemia, and high levels of serum IL-6 [6]. Several mechanisms have been proposed to be responsible for the activation of this acute response [17]. However, regardless of the multiple mechanisms involved, systemic administration of Ad results in an acute toxic reaction which is triggered by the Ad capsid proteins in a dose-dependent fashion [15]. This acute toxicity is currently the main obstacle preventing clinical application of HDAd and strategies to overcome this problem are currently under investigation [18-20].

\section{Adeno-associated virus (AAV)}

AAV vectors are derived from a non-pathogenic human parvovirus that can infect non-dividing cells and remains latent for prolonged periods, predominantly in an episomal state. AAV vectors appear to persist in infected cells and do not trigger a robust innate response following in vivo administration. A wide repertoire of different AAV serotypes with different tissue tropisms is now available for several disease applications [21]. AAV vectors have a limited packaging capacity which precludes applications in diseases requiring large therapeutic genes. However, novel AAV serotypes with larger cloning capacity are emerging and they may at least in part overcome this problem [22]. In the clinical study for liver-directed gene therapy of hemophilia B, a recombinant AAV vector expressing human Factor IX (FIX) was infused through the hepatic artery in subjects with severe hemophilia B in an open label, dose-escalation study. Two subjects in the higher dose cohorts achieved measurable FIX levels at 2 weeks after vector infusion but, in contrast to the results generated in animal models, they exhibited a gradual decline in factor levels to $<1 \%$ by 10 weeks after vector infusion. This was accompanied in both subjects by an asymptomatic transaminase elevation beginning 4 weeks after vector infusion, with a gradual decline to baseline normal levels coinciding with the loss of FIX expression [23]. This reaction is due to the rejection of transduced hepatocytes by AAV capsid-specific memory CD8(+) T cells reactivated by AAV [24] and intense investigations are currently ongoing to overcome this problem. Another problem of the AAV vectors is as yet theoretical risk of insertional mutagenesis in humans. Studies in mice suggest that AAV vectors are predominantly nonintegrating [25], and a wealth of experience in the field had failed to uncover any evidence of tumor formation as a result of AAV transduction, except for a mouse disease model of mucopolysaccharidosis type VII [26]. A recent study has reported that, in the tumor tissue, the vector appeared to have integrated in a region rich in microRNA sequences on mouse chromosome 12 [27]. On the other hand, follow-up periods ranging up to 9 years in several hemophilic dogs have failed to reveal any evidence of tumor formation [28].

\section{Nonviral vectors}

Nonviral vectors offer a number of advantages over viralbased strategies, including minimal toxicity from the vector, long-term transgene expression, lack of a humoral response against the vector, and the consequent ability to repeat dose [29]. A major advance in the field has been the development of the hydrodynamic injection technique which involves, in mice, the rapid injection of a large volume of naked plasmid DNA (pDNA) and typically results in $10-15 \%$ of hepatocyte transfection [30,31]. Systemic hydrodynamic procedure as practiced in the rodents is neither safe nor practical in larger animals or humans. However, clinically relevant methods using balloon catheters for regional hydrodynamic delivery of pDNA have been developed $[32,33]$. These studies demonstrate the feasibility of intravascular delivery to the liver using minimally invasive approaches, and are a step in the direction of human clinical trials.

\section{Pre-clinical and clinical studies}

Experimental gene therapy has been used to correct several metabolic diseases. We will discuss two diseases (Crigler-Najjar syndrome type I and OTCD) as representative examples to illustrate the potential and the limitations of 
currently available strategies for liver-directed gene therapy.

\section{Crigler-Najjar syndrome}

Crigler-Najjar syndrome is an autosomal recessive condition characterized by non-hemolytic unconjugated hyperbilirubinaemia due to mutations bilirubinuridinediphosphoglucuronate glucuronosyltransferase (UGT1A1). Patients with Crigler-Najjar syndrome type I (MIM 218800) are refractory to phenobarbital treatment, have life-threatening elevations of bilirubin, and are generally managed with phototherapy throughout childhood and adolescence. Although effective, phototherapy is cumbersome, inconvenient, and its efficacy may diminish with age because of increased skin thickness and decreased surface/mass ratio. Moreover, despite this treatment, patients remain at risk of brain damage when intercurrent infections may increase production of bilirubin above that which can be controlled by the phototherapy [34]. Therefore, patients with Crigler-Najjar type I are often advised to consider liver transplantation, most frequently in the range of $18-25$ years of age. Crigler-Najjar syndrome has long been considered a paradigm for developing gene therapies for metabolic liver diseases for several reasons: $(a)$ the underlying defect is well characterized at the biochemical and molecular level; $(b)$ the fraction of corrected hepatocytes required for clinical benefit is small, as deduced from hepatocyte transplantation studies [35]; (c) the UGT1A1 does not require strict gene regulation for normal activity; $(d)$ an animal model, the Gunn rat, recapitulating the human disease is available; (e) the outcome of the experimental therapies can be easily determined by measuring bilirubin fractions in serum and bile; $(f)$ the UGT1A1 can be produced from skeletal muscle other than liver, its natural production site, and still retain the ability to transform bilirubin into water-soluble derivatives [36]. For these several reasons, Crigler-Najjar syndrome type I is very attractive as a gene therapy disease candidate and its correction has been the goal of several studies using different vector systems including RV, LV, Ad, AAV, and nonviral vectors. RV expressing UGT1A1 injected in newborns [37] or in conjunction with partial hepatectomy [38] have achieved long-term correction of the hyperbilirubinemia in the Gunn rats. As previously discussed, LV can also transduce nonproliferating cells and, in the Gunn rats, they resulted in stable reduction of bilirubin levels to near normal levels for over 1 year after treatment [39]. Impressive lifelong correction of hyperbilirubinemia has been also reported in the Gunn rats following a single intravenous injection of HDAd vector encoding UGT1A1 with negligible chronic toxicity [40]. Among different serotypes, AAV serotype 1 was found to be the most efficient in correcting the hyperbilirubinemia of the Gunn rats although large hepatic macroscopic lipid lesions of unclear etiology were found in AAV-treated animals [41].
A reduction of hyperbilirubinemia has also been reported following hydrodynamic injection of pDNA [42]. However, as discussed in previous sections, each of the vectors used in this disease model has some limitations which are currently preventing clinical applications.

\section{Urea cycle disorders}

Urea cycle disorders typically present in the first few days after birth with poor feeding, vomiting, lethargy, and coma due to hyperammonemia. Despite aggressive pharmacotherapy, patients are at high risk for repeated episodes of hyperammonemia and cumulative neurological morbidity and mortality $[43,44]$. Given these significant problems, gene-replacement therapy could represent a viable alternative to OLT for long-term correction. Several studies over the past decade have found the therapeutic effect of several different FGAd vectors to be transient in the OTCD mouse models and lasting no longer than 2 months [45]. HDAd instead can mediate long-term correction of the OTCD animal model without chronic toxicity $[46,47]$. The novel AAV serotypes (AAV7, 8, 9), with higher efficiency of hepatocyte transduction, have also resulted in long-term phenotypic correction [48]. The application of LV and nonviral vectors for OTCD has not been reported to date and these vectors are likely to be inefficient in these diseases due to the high percentage of hepatocyte correction required.

\section{Conclusion}

Gene therapy for liver metabolic diseases as an alternative or adjunctive treatment to cell therapy is a logical target given the problems with the available treatment modalities. Disorders such as Crigler-Najjar syndrome and urea cycle disorders are excellent candidates because of their poor prognosis. However, each of the available vector transfer technologies offers strengths and weaknesses. Integrating vectors such as LV and RV may be associated with long-term risk of genotoxicity and potential life long correction; AAV have a lower risk regarding integration, but are limited by cloning capacity and potential adaptive immune response to viral antigens. HDAd are associated with a dose-related innate immune response but offers efficient transduction without risk of genome integration. None of these obstacles are conceptually immovable and novel strategies need to be investigated to improve the safety profile of these vectors. Based on the significant progress to date, in spite of the expected setbacks of all drug development efforts, gene therapy for liver metabolic disorders may soon become a clinical reality.

\section{Competing interests}

The author declares that she has no competing interests.

\section{Acknowledgements}

NB-P is supported by the National Institutes of Health (K99 DK077447), the Texas Affiliate of the American Heart Association (0765032Y), and the 
Texas Medical Center Digestive Disease Center. The financial support of Telethon - Italy (Fellowship GFP04008) to NB-P is gratefully acknowledged.

\section{References}

I. McCabe LL, McCabe ER: Expanded newborn screening: implications for genomic medicine. Annu Rev Med 2008, 59:163-175.

2. Teckman J, Perlmutter DH: Conceptual advances in the pathogenesis and treatment of childhood metabolic liver disease. Gastroenterology 1995, 108:1263-1279.

3. Toso C, Ris F, Mentha G, Oberholzer J, Morel P, Majno P: Potential impact of in situ liver splitting on the number of available grafts. Transplantation 2002, 74:222-226.

4. Newstead CG: Assessment of risk of cancer after renal transplantation. Lancet 1998, 35 1:610-611.

5. Shneider BL: Pediatric liver transplantation in metabolic disease: clinical decision making. Pediatr Transplant 2002, 6:25-29.

6. Raper SE, Chirmule N, Lee FS, Wivel NA, Bagg A, Gao GP, Wilson $J M$, Batshaw ML: Fatal systemic inflammatory response syndrome in a ornithine transcarbamylase deficient patient following adenoviral gene transfer. Mol Genet Metab 2003, 80:148-158.

7. Hacein-Bey-Abina S, von Kalle C, Schmidt M, McCormack MP, Wulffraat N, Leboulch P, Lim A, Osborne CS, Pawliuk R, Morillon E, Sorensen R, Forster A, Fraser P, Cohen Jl, de Saint Basile G, Alexander I, Wintergerst U, Frebourg T, Aurias A, Stoppa-Lyonnet D, Romana S, Radford-Weiss I, Gross F, Valensi F, Delabesse E, Macintyre E, Sigaux F, Soulier J, Leiva LE, Wissler M, Prinz C, Rabbitts TH, Le Deist F, Fischer A, Cavazzana-Calvo M: LMO2-associated clonal $T$ cell proliferation in two patients after gene therapy for SCID-XI. Science 2003, 302:4I5-4I9.

8. Hacein-Bey-Abina S, Le Deist F, Carlier F, Bouneaud C, Hue C, De Villartay JP, Thrasher AJ, Wulffraat N, Sorensen R, Dupuis-Girod S, Fischer A, Davies EG, Kuis W, Leiva L, Cavazzana-Calvo M: Sustained correction of $X$-linked severe combined immunodeficiency by ex vivo gene therapy. N Engl J Med 2002, 346: $1185-1193$.

9. Ferry N, Duplessis O, Houssin D, Danos O, Heard JM: Retroviralmediated gene transfer into hepatocytes in vivo. Proc Natl Acad Sci USA 1991, 88:8377-8381.

10. Kay MA, Rothenberg S, Landen CN, Bellinger DA, Leland F, Toman $C$, Finegold M, Thompson AR, Read MS, Brinkhous KM: In vivo gene therapy of hemophilia B: sustained partial correction in factor IX-deficient dogs. Science 1993, 262: I I7-II9.

II. Patijn GA, Lieber A, Schowalter DB, Schwall R, Kay MA: Hepatocyte growth factor induces hepatocyte proliferation in vivo and allows for efficient retroviral-mediated gene transfer in mice. Hepatology 1998, 28:707-716.

12. VandenDriessche T, Vanslembrouck V, Goovaerts I, Zwinnen H, Vanderhaeghen ML, Collen D, Chuah M: Long-term expression of human coagulation factor VIII and correction of hemophilia A after in vivo retroviral gene transfer in factor VIII-deficient mice. Proc Natl Acad Sci USA 1999, 96: 10379-10384.

13. Xu L, Gao C, Sands MS, Cai SR, Nichols TC, Bellinger DA, Raymer RA, McCorquodale S, Ponder KP: Neonatal or hepatocyte growth factor-potentiated adult gene therapy with a retroviral vector results in therapeutic levels of canine factor IX for hemophilia B. Blood 2003, 101:3924-3932.

14. Brunetti-Pierri N, Ng P: Progress and prospects: gene therapy for genetic diseases with helper-dependent adenoviral vectors. Gene Ther 2008, 15:553-560.

15. Brunetti-Pierri N, Palmer DJ, Beaudet AL, Carey KD, Finegold M, Ng $\mathrm{P}$ : Acute toxicity after high-dose systemic injection of helperdependent adenoviral vectors into nonhuman primates. Hum Gene Ther 2004, 15:35-46.

16. Raper SE, Yudkoff M, Chirmule N, Gao GP, Nunes F, Haskal ZJ, Furth EE, Propert KJ, Robinson MB, Magosin S, Simoes H, Speicher L, Hughes J, Tazelaar J, Wivel NA, Wilson JM, Batshaw ML: A pilot study of in vivo liver-directed gene transfer with an adenoviral vector in partial ornithine transcarbamylase deficiency. Hum Gene Ther 2002, 13:163-175.

17. Seiler MP, Cerullo V, Lee B: Immune response to helper dependent adenoviral mediated liver gene therapy: challenges and prospects. Curr Gene Ther 2007, 7:297-305.
18. Brunetti-Pierri N, Stapleton GE, Palmer DJ, Zuo Y, Mane VP, Finegold MJ, Beaudet AL, Leland MM, Mullins CE, Ng P: Pseudo-hydrodynamic delivery of helper-dependent adenoviral vectors into non-human primates for liver-directed gene therapy. Mol Ther 2007, I 5:732-740.

19. Mok H, Palmer DJ, Ng P, Barry MA: Evaluation of polyethylene glycol modification of first-generation and helper-dependent adenoviral vectors to reduce innate immune responses. Mol Ther 2005, I I:66-79.

20. Croyle MA, Le HT, Linse KD, Cerullo V, Toietta G, Beaudet A, Pastore L: PEGylated helper-dependent adenoviral vectors: highly efficient vectors with an enhanced safety profile. Gene Ther 2005, I 2:579-587.

21. Gao GP, Alvira MR, Wang L, Calcedo R, Johnston J, Wilson JM: Novel adeno-associated viruses from rhesus monkeys as vectors for human gene therapy. Proc Natl Acad Sci USA 2002, 99:11854-11859.

22. Allocca M, Doria M, Petrillo M, Colella P, Garcia-Hoyos M, Gibbs D Kim SR, Maguire A, Rex TS, Di Vicino U, Cutillo L, Sparrow JR, Williams DS, Bennett J, Auricchio A: Serotype-dependent packaging of large genes in adeno-associated viral vectors results in effective gene delivery in mice. J Clin Invest 2008, I I 8: I 955- I 964.

23. Manno CS, Pierce GF, Arruda VR, Glader B, Ragni M, Rasko IJ, Ozelo MC, Hoots K, Blatt P, Konkle B, Dake M, Kaye R, Razavi M, Zajko A, Zehnder J, Rustagi PK, Nakai H, Chew A, Leonard D, Wright JF, Lessard RR, Sommer JM, Tigges M, Sabatino D, Luk A, Jiang H, Mingozzi F, Couto L, Ertl HC, High KA, Kay MA: Successful transduction of liver in hemophilia by AAV-Factor IX and limitations imposed by the host immune response. Nat Med 2006, I 2:342-347.

24. Mingozzi F, Maus MV, Hui DJ, Sabatino DE, Murphy SL, Rasko JE, Ragni MV, Manno CS, Sommer J, Jiang H, Pierce GF, Ertl HC, High KA: CD8(+) T-cell responses to adeno-associated virus capsid in humans. Nat Med 2007, 13:419-422.

25. Nakai H, Yant SR, Storm TA, Fuess S, Meuse L, Kay MA: Extrachromosomal recombinant adeno-associated virus vector genomes are primarily responsible for stable liver transduction in vivo. J Virol 2001, 75:6969-6976.

26. Donsante A, Vogler C, Muzyczka N, Crawford JM, Barker J, Flotte T, Campbell-Thompson M, Daly T, Sands MS: Observed incidence of tumorigenesis in long-term rodent studies of rAAV vectors. Gene Ther 200I, 8: I343-I346.

27. Donsante A, Miller DG, Li Y, Vogler C, Brunt EM, Russell DW, Sands MS: AAV vector integration sites in mouse hepatocellular carcinoma. Science 2007, 317:477.

28. Hasbrouck NC, High KA: AAV-mediated gene transfer for the treatment of hemophilia B: problems and prospects. Gene Ther 2008, I5:870-875.

29. Niidome T, Huang L: Gene therapy progress and prospects: nonviral vectors. Gene Ther 2002, 9:1647-1652.

30. Liu F, Song Y, Liu D: Hydrodynamics-based transfection in animals by systemic administration of plasmid DNA. Gene Ther 1999, 6: I 258-1266.

3I. Zhang G, Budker V, Wolff JA: High levels of foreign gene expression in hepatocytes after tail vein injections of naked plasmid DNA. Hum Gene Ther 1999, 10:1735-1737.

32. Eastman SJ, Baskin KM, Hodges BL, Chu Q, Gates A, Dreusicke R, Anderson S, Scheule RK: Development of catheter-based procedures for transducing the isolated rabbit liver with plasmid DNA. Hum Gene Ther 2002, 13:2065-2077.

33. Alino SF, Herrero MJ, Noguera I, Dasi F, Sanchez M: Pig liver gene therapy by noninvasive interventionist catheterism. Gene Ther 2007, 14:334-343.

34. Strauss KA, Robinson DL, Vreman HJ, Puffenberger EG, Hart G, Morton $\mathrm{DH}$ : Management of hyperbilirubinemia and prevention of kernicterus in 20 patients with Crigler-Najjar disease. Eur J Pediatr 2006, 165:306-319.

35. Fox IJ, Chowdhury JR, Kaufman SS, Goertzen TC, Chowdhury NR, Warkentin PI, Dorko K, Sauter BV, Strom SC: Treatment of the Crigler-Najjar syndrome type I with hepatocyte transplantation. N EnglJ Med 1998, 338: 1422-1426.

36. Jia Z, Danko I: Long-term correction of hyperbilirubinemia in the Gunn rat by repeated intravenous delivery of naked plasmid DNA into muscle. Mol Ther 2005, 1 2:860-866.

37. Bellodi-Privato M, Aubert D, Pichard V, Myara A, Trivin F, Ferry N: Successful gene therapy of the Gunn rat by in vivo neonatal 
hepatic gene transfer using murine oncoretroviral vectors. Hepatology 2005, 42:43I-438.

38. Tada K, Chowdhury NR, Neufeld D, Bosma PJ, Heard M, Prasad VR, Chowdhury JR: Long-term reduction of serum bilirubin levels in Gunn rats by retroviral gene transfer in vivo. Liver Transpl Surg 1998, 4:78-88.

39. Wegen $P$ van der, Louwen R, Imam AM, Buijs-Offerman RM, Sinaasappel M, Grosveld F, Scholte BJ: Successful treatment of UGTIAI deficiency in a rat model of Crigler-Najjar disease by intravenous administration of a liver-specific lentiviral vector. Mol Ther 2006, 13:374-38I.

40. Toietta G, Mane VP, Norona WS, Finegold MJ, Ng P, McDonagh AF, Beaudet $A L$, Lee $B$ : Lifelong elimination of hyperbilirubinemia in the Gunn rat with a single injection of helper-dependent adenoviral vector. Proc Natl Acad Sci USA 2005, 102:3930-3935.

41. Seppen J, Bakker C, de Jong B, Kunne C, Oever K van den, Vandenberghe K, de Waart R, Twisk J, Bosma P: Adeno-associated virus vector serotypes mediate sustained correction of bilirubin UDP glucuronosyltransferase deficiency in rats. Mol Ther 2006, 1 3:1085-1092

42. Jia Z, Danko I: Single hepatic venous injection of liver-specific naked plasmid vector expressing human UGTIAI leads to long-term correction of hyperbilirubinemia and prevention of chronic bilirubin toxicity in Gunn rats. Hum Gene Ther 2005, 16:985-995.

43. Maestri NE, Clissold D, Brusilow SW: Neonatal onset ornithine transcarbamylase deficiency: A retrospective analysis. J Pediatr 1999, 134:268-272.

44. Bachmann C: Outcome and survival of $\mathbf{8 8}$ patients with urea cycle disorders: a retrospective evaluation. Eur J Pediatr 2003, 162:410-416.

45. Ye X, Robinson MB, Batshaw ML, Furth EE, Smith I, Wilson JM: Prolonged metabolic correction in adult ornithine transcarbamylase-deficient mice with adenoviral vectors. I Biol Chem 1996, 271:3639-3646.

46. Mian A, McCormack WM Jr, Mane V, Kleppe S, Ng P, Finegold M, O'Brien WE, Rodgers JR, Beaudet AL, Lee B: Long-term correction of ornithine transcarbamylase deficiency by WPREmediated overexpression using a helper-dependent adenovirus. Mol Ther 2004, 10:492-499.

47. Brunetti-Pierri N, Clarke C, Mane V, Palmer DJ, Lanpher B, Sun Q, O' Brien W, Lee B: Phenotypic correction of ornithine transcarbamylase deficiency using low dose helper-dependent adenoviral vectors. J Gene Med 2008, 10:890-896.

48. Moscioni D, Morizono $H$, McCarter RJ, Stern A, Cabrera-Luque J, Hoang A, Sanmiguel J, Wu D, Bell P, Gao GP, Raper SE, Wilson JM, Batshaw ML: Long-term correction of ammonia metabolism and prolonged survival in ornithine transcarbamylase-deficient mice following liver-directed treatment with adenoassociated viral vectors. Mol Ther 2006, 14:25-33.
Publish with Biomed Central and every scientist can read your work free of charge

"BioMed Central will be the most significant development for disseminating the results of biomedical research in our lifetime. "

Sir Paul Nurse, Cancer Research UK

Your research papers will be:

- available free of charge to the entire biomedical community

- peer reviewed and published immediately upon acceptance

- cited in PubMed and archived on PubMed Central

- yours - you keep the copyright

Submit your manuscript here:

http://www.biomedcentral.com/info/publishing_adv.asp
BioMedcentral 